\title{
Possible Synergistic Effect and Antioxidant Properties of Chitosan Nanoparticles and Quercetin against Carbon Tetrachloride- Induce Hepatotoxicity in Rats
}

\author{
Ezzeldeen S. El-Denshary1, Abdulhadi Aljawish2, Aziza A. El-Nekeety3, Nabila S. Hassan", \\ Raghda H. Saleh", Bertrand H. Rihn', Mosaad A. Abdel-Wahhab ${ }^{3 *}$ \\ ${ }^{1}$ Toxicology \& Pharmacology Department, Faculty of Pharmacy, Cairo University, Cairo, Egypt \\ ${ }^{2}$ Laboratoire d'Ingénierie des Biomolécules (LIBio), Université de Lorraine, Nancy, France \\ ${ }^{3}$ Food Toxicology \& Contaminants Department, National Research Center, Cairo, Egypt \\ ${ }^{4}$ Pathology Department, National Research Center, Cairo, Egypt \\ ${ }^{5}$ Faculty of Pharmacy, Lorraine University, Nancy, France \\ Email: ${ }^{\text {mosaad abdelwahhab@yahoo.com }}$
}

Received 14 April 2015; accepted 28 April 2015; published 4 May 2015

Copyright (C) 2015 by authors and Scientific Research Publishing Inc.

This work is licensed under the Creative Commons Attribution International License (CC BY). http://creativecommons.org/licenses/by/4.0/

(c) (i) Open Access

\section{Abstract}

This study was conducted to prepare chitosan nanoparticles (CNPs), to determine their properties and to evaluate the synergistic protective role of CNPs alone or in combination with quercetin (Q) against oxidative stress and hepatotoxicity in rats. Female Sprague-Dawley rats were divided into 12 groups (7 rats/group) and were maintained on their respective diet for 3 weeks as follow: control group, the group treated with $\mathrm{CCl}_{4}(100 \mathrm{mg} / \mathrm{kg}$ b.w twice a week); the groups received CNPs at low and high doses (140 and $280 \mathrm{mg} / \mathrm{kg} \mathrm{b.w);} \mathrm{the} \mathrm{group} \mathrm{received} Q(50 \mathrm{mg} / \mathrm{kg} \mathrm{b.w})$; the groups received CNPs at the low or high doses plus $Q$ and the groups treated with $\mathrm{CCl}_{4}$ plus $\mathrm{Q}$ and/or $\mathrm{CNPs}$ at the two tested doses. Blood and liver samples were collected at the end of experiment period for biochemical and histological studies. The results indicated that chitosan showed deacetylation degree of $17.5 \%$ and $19.2 \%$ and the molar mass average of monomer was $168.35 \mathrm{~g} / \mathrm{mol}$ and 169.1 $\mathrm{g} / \mathrm{mol}$ by UV and IR methods respectively. The particle size of CNPs was around $100 \mathrm{~nm}$ with a rough surface. The in vivo results revealed that $\mathrm{CCl}_{4}$ induced biochemical and histological changes typical to those reported in the literature. Animals treated with CNPs at the two tested doses alone or in combination with $Q$ were comparable to the control. CNPs alone or plus $Q$ succeeded to induce significant improvements in the biochemical parameters and histological picture of the liver in rats treated with $\mathrm{CCl}_{4}$. This improvement was in dose-dependent manner for CNPs and was

\footnotetext{
${ }^{*}$ Corresponding author.
}

How to cite this paper: El-Denshary, E.S., et al. (2015) Possible Synergistic Effect and Antioxidant Properties of Chitosan Nanoparticles and Quercetin against Carbon Tetrachloride-Induce Hepatotoxicity in Rats. Soft Nanoscience Letters, 5, 36-51. http://dx.doi.org/10.4236/snl.2015.52005 
more pronounced in the group treated with the high dose plus $Q$. It could be concluded that both CNPs and $Q$ could induce protection against hepatotoxicity. Consequently, CNPs was a promise candidate as drug delivery in liver diseases treatments.

\author{
Keywords
}

Nanochitosan, Quercetin, Liver, Antioxidant, Oxidative Stress

\title{
1. Introduction
}

Hepatocellular carcinoma (HCC) is the sixth most common cancer worldwide and the third most common cause of cancer-related death [1]. It is representing $90 \%$ of primary liver cancer worldwide and its incidence is dramatically increasing in the United States, Western Europe and Japan [2] [3]. In the last two decades, no significant improvement in the survival rate of patients with HCC and till now no available drug is able to prevent or reduce tumor spread and/or recurrence [4]. According to $\mathrm{Xu}$ et al. [5], chemotherapy and radiotherapy are avoided in the treatment of this disease due to associated liver toxicity.

Chitosan is a natural polysaccharide consisting of varying amounts of (1-4)-glycosidic bonds linking N-acetyl2-amino-2-deoxy-Dglucopyranose (glucosamine) and 2-amino-2-deoxy-D-glucopyranose (N-acetyl-gluamine) [6]. Chitosan has attracted much attention as a biomedical material, as it exhibits a wide variety of biological activities, such as antitumor activities [7]-[9], immunostimulating effects [10], antiallergic effects [11], hemostatic agent [12], anticoagulant effects [13] [14] hypocholesterolemic effects [15], antiinflammatorty activities [16], free radical scavenging activities [17], antimicrobial effects [18], antibacterial effects [19] [20] wound-healing effects [21] [22], antifungal activities [23] [24] and antiviral activity [25]. However, because of its high molecular weight and water-insolubility, the applications of chitosan are severely limited. As a solution, nanoparticle formulation provides a plausible pharmaceutical basis for enhancing oral bioavailability and therapeutic efficacy of chitosan and other drugs that are poorly soluble [26]. Chitosan nanoparticles (CNPs) exhibit more superior activities than chitosan and have been reported to have heightened immune-enhancing effect, anticancer activity and antimicrobial activity than those of chitosan. In addition, nanoparticles possess a stronger curvature of the surface, compared to large particles; this produces more dissolution pressure with a corresponding increase in saturation solubility [27]. The increased saturation solubility, in turn, favors an increase in concentration gradient between intestinal epithelial cells and the mesenteric circulation beneath.

Quercetin (Q) is one of the most abundant flavonoids in the human diet, which is found in fruits and vegetables such as blueberries, onions, broccoli and leek [28] [29]. It is well documented that Q has broad bioactivity, such as anti-proliferative and anticancer properties [30] [31], anti-fibrotic [32] [33], anti-coagulative [34], antibacterial [35], anti-atherogenic [36] [37], anti-hypertensive [38] [39] and anti-inflammatory capacities [40]-[43]. However, the antioxidant effects of quercetin have been closely linked with the potential generation of reactive pro-oxidant intermediates resulting in mutagen and genotoxicant [44]. In an in vitro study, quercetin has showed positive mutagenic activity in most standard strains of Salmonella typhimurium [45] [46]. Moreover, In Escherichia coli, quercetin has been shown to induce SOS activity, reverse mutations, and DNA single strand breaks with or without metabolic activation [46]-[49]. These positive mutagenic and genotoxic responses in bacterial test systems have been confirmed in eukaryotic cells, including yeast [50] and mammalian cells included mouse, hamster, rat and human [51]-[55], in which sister chromatid exchanges, chromosomal aberrations, unscheduled DNA synthesis (UDS), and micronucleus formation are among some of the endpoints evaluated. However, in a study for a 2-year rodent carcinogenicity bioassay conducted by the National Toxicology Program (NTP), these genotoxic effects have not confirmed suggesting the safety of quercetin for oral consumption in humans [52] [56] [57]. These results are supported by Utesch et al. [58] who demonstrate that quercetin is not genotoxic in vivo following oral exposure.

Many serious problems are associated with the therapeutic use of poorly water-soluble drugs. This includes poor absorption and bioavailability upon oral administration, embolization of blood vessels from intravenous injection of the water-insoluble drug because of drug precipitation, and local tissue toxicity and low systemic drug bioavailability [59]. Consequently, the aims of the current study are to prepare chitosan nanoparticles 
(CNPs), to study the characterization of CNPs and to evaluate the protective role of CNPs alone or in combination with quercetin against oxidative stress and hepatotoxicity induced by carbon tetrachloride $\left(\mathrm{CCl}_{4}\right)$ in rat.

\section{Materials and Methods}

\subsection{Chemicals and Kits}

Chitosan was purchased from Sigma-Aldrich (France). Quercetin extract was purchased from Sigma Chemical Co. (St. Louis, MO, USA). Carbon tetrachloride $\left(\mathrm{CCl}_{4}\right)$ was supplied by Merck/Schuchardt (Darmstadt, Germany). Alanine aminotransferase (ALT) and Aspartate aminotransferase (AST) kits were purchased from Spectrumdiagnostics Co. (Cairo, Egypt). Alkaline phosphatase (ALP), glutathione peroxidase (GPx), superoxide dismutase (SOD), lipid peroxidation (MDA), catalase, alpha fetoprotein (AFP) and carcinoembrionic antigen (CEA) kits were purchased from Biodiagnostic Co. (Giza, Egypt). All other chemicals used throughout the experiments were of the highest analytical grade available.

\subsection{Characterization of Chitosan}

The acetylation degree of chitosan (DA\%) was determined by UV spectrophotometric as described previously [60]. The molar mass average of chitosan monomer and the concentration of free amino groups in chitosan were measured according to the method described by Aljawish et al. [61]. The molecular weight of chitosan was evaluated using size exclusion chromatography with multi-angle laser light scattering detectors (SEC-MALLS) [62]. All measurements were carried out at least in triplicate.

\subsection{Preparation of Chitosan Nanoparticles (CNPs)}

Twenty mg chitosan was dissolved in $40 \mathrm{ml}$ of $2.0 \%$ (v/v) acetic acid. A $20 \mathrm{ml}$ of $0.75 \mathrm{mg} / \mathrm{ml}$ sodium tripolyphosphate was dropped slowly with stirring. CNPs as a suspension were collected and stored in deionised water. Supernatant was discarded and CNPs were air dried for further use and analysis [63].

\subsection{Determination of Particles size and Morphology of CNPs}

Size and morphology of CNPs were analyzed using Nanotrac analyzer 6Hx4Wx15D, Model-Nanotrac 150 with a measuring range of $0.8-6500 \mathrm{~nm}$. CNPS were cut into pieces of various sizes and wiped with a thin goldpalladium layer by a sputter coater unit (UG-microtech, UCK field, UK) and the morphology of nanoparticles was analyzed with a Cambridge stereoscan 440 scanning electron microscope (SEM, Leica, Cambridge, UK). Atomic force microscopy (AFM) was used for visualization of CNPs rough nature and AFM imaging was performed using CONTR, EZ-2-AFM analysis.

\subsection{Experimental Animals}

Three-month old female Sprague-Dawley rats (100 - 150 g each) were purchased from Animal House Colony, National Research Centre, Dokki, Giza, Egypt. Animals were maintained on standard lab diet (protein: 160.4; fat: 36.3; fiber: $41 \mathrm{~g} / \mathrm{kg}$, namely 12.1 MJ of metabolized energy) purchased from Meladco Feed Co. (Aubor City, Cairo, Egypt) and housed in filter-top polycarbonate cages in a room free from any source of chemical contamination, artificially illuminated (12 h dark/light cycle) and thermally controlled $\left(25^{\circ} \mathrm{C} \pm 1{ }^{\circ} \mathrm{C}\right)$ at the Animal House Lab., National Research Centre, Dokki, Cairo, Egypt. All animals were received humane care in compliance with the guidelines of the Animal Care and Use Committee of the National Research Centre, Dokki, Giza, Egypt and the National Institute of Health (NIH publication 86 - 23 revised 1985).

\subsection{Experimental Design}

Animals were divided into twelve groups (7 rats/group) and were maintained on their respective diet and treated orally for 3 weeks as follow: group 1, normal control animals fed on basal diet and received $0.5 \mathrm{ml}$ saline solution; Group 2, animals treated orally with $\mathrm{CCl}_{4}$ suspended in corn oil (1.0 ml $/ \mathrm{kg}$ b.w.) twice a week; Groups 3 and 4, animals treated daily with low and high dose of chitosan nanoparticles CNPs (140 and $280 \mathrm{mg} / \mathrm{kg}$ b.w.) respectively susbended in saline solution; Group 5, animals treated daily with quercetin ( $50 \mathrm{mg} / \mathrm{kg}$ b.w.) in saline solution; Groups 6 and 7, animals treated orally with quercetin plus low and high dose of CNPs respectively; 
Groups 8 and 9, animals treated orally with $\mathrm{CCl}_{4}$ plus the low and high dose of CNPs respectively; Group 10, animals treated orally with quercetin plus $\mathrm{CCl}_{4}$; Groups 11 and 12 , animals treated orally $\mathrm{CCl}_{4}$ plus quercetin and low and high dose of CNPs respectively.

The animals were observed daily for signs of toxicity during the experimental period. At the end of the treatment period (i.e. day 21), all animals were fasted for $12 \mathrm{~h}$, then blood samples were collected from the retro-orbital venous plexus under diethyl ether anesthesia. Sera were separated using cooling centrifugation and stored at $-20^{\circ} \mathrm{C}$ until analysis. The sera were used for the determination of ALT, AST, ALP, CEA, and AFP according to the kits instructions using spectrophotometer.

After the collections of blood samples, animals were sacrificed and samples of the right lobe of the liver of each animal were dissected, weighed and were homogenized in phosphate buffer ( $\mathrm{pH} 7.4$ ) to give $20 \% \mathrm{w} / \mathrm{v}$ homogenate according to Lin et al. [64]. This homogenate was centrifuged at $1700 \mathrm{rpm}$ and $40^{\circ} \mathrm{C}$ for $10 \mathrm{~min}$; the supernatant was stored at $-70^{\circ} \mathrm{C}$ until analysis. This supernatant (20\%) was used for the colometricaly determination of hepatic lipid peroxidation expressed as $n$ mol malondialdehyde (MDA)/g liver tissue according to the kits instructions. The homogenate was further diluted with phosphate buffer solution to give $2 \%$ and $0.5 \%$ dilutions for the colometricaly determination of hepatic glutathione peroxidase (GPx), catalase and superoxide dismutase (SOD) activities, respecetively according to the kits instructions. Other samples of liver were hydrated in ascending grades of ethanol, cleared in xylene and embedded in paraffin. Sections of $5 \mu \mathrm{m}$ thick were cut and stained with hematoxylin and eosin ( $\mathrm{H} \& \mathrm{E}$ ) for histological examination and Masson's trichrome for connective tissue namely collagen evaluation [65]. The area percentage of collagen fibers were measured by image analyzer system.

\subsection{Statistical Analysis}

All data for biochemicall analysis and the numerical values of area\% of collagen were statistically analyzed using the General Linear Models Procedure of the Statistical Analysis System [66]. The significance of the differences among treatment groups was determined by Waller-Duncan k-ratio [67]. All statements of significance were based on probability of $\mathrm{P} \leq 0.05$.

\section{Results}

The characterization results of the chitosan showed a deacetylation degree of $87.5 \% \pm 0.5 \%$. The molar mass average of monomer was $169.35 \pm 0.3 \mathrm{~g} / \mathrm{mol}$ and the molecular weight of chitosan was $90 \pm 5 \mathrm{kDa}$. The results also revealed that the concentration of free amino groups was $0.048 \pm 0.002 \mathrm{~mol} / \mathrm{L}$.

The scanning electron microscopy (SEM) images of CNPs in the nanorod form are presented in Figure 1. CNPs were analyzed for its particle size and distribution using Nanotrac analyzer. The results indicated that the minimum particles size of CNPs was around $100 \mathrm{~nm}$ and distribution in the range of $100-400 \mathrm{~nm}$. The Atomic force microscopy (AFM) topography of CNPs indicating the rough nature of the surface, due to the rod shaped CNPs (Figure 1).

The in vivo biochemical results indicated that the treatment with $\mathrm{CCl}_{4}$ showed a significant increase in AST, ALT, ALP, CEA and AFP (Table 1) and oxidative stress markers (MDA) accompanied with a significant decrease in antioxidant enzymes (GPx, SOD and catalase) in liver (Table 2). However, treatment with CNPs at the low dose (CNPs-LD) or the high dose (CNPs-HD) showed a significant decrease in AST, ALT, ALP, CEA and AFP except in the group treated with CNPs-HD and AFP in the group received CNP-D when compared to the control group. Whereas, animals treated with quercetin $(\mathrm{Q})$ alone or plus CNPs at the two tested doses were comparable to the control group in the ALT, AST and ALP except ALP in the group received Q plus CNPs-HD which showed a significant decrease compared to the control group. Moreover, these groups showed a significant decrease in the tumor markers indices AFP and CEA except AFP in the group received CNPs-HD which was found to be in the normal range of the control group. ALT in animals treated with $\mathrm{CCl}_{4}$ and $\mathrm{Q}$ or Q plus CNPs-LD were comparable to the control group whereas; ALT, AST and ALP in animals treated with $\mathrm{CCl}_{4} \mathrm{plus}$ $\mathrm{Q}$ and CNPs-HD were comparable to the control group. In general, the companied treatment with Q and CNPs at the two tested doses succeeded to induce a significant improvement in liver function parameters. On the other hand, AFP and CEA in the groups treated with $\mathrm{CCl}_{4}$ plus Q alone or Q plus CNPs-LLD or CNPs-HD were significantly decreased compared to the control group except CEA in the group treated with $\mathrm{CCl}_{4}$ plus CNPs-LD which was comparable to the control. It is of interest to mention that the decrease in AFP level was more pro- 


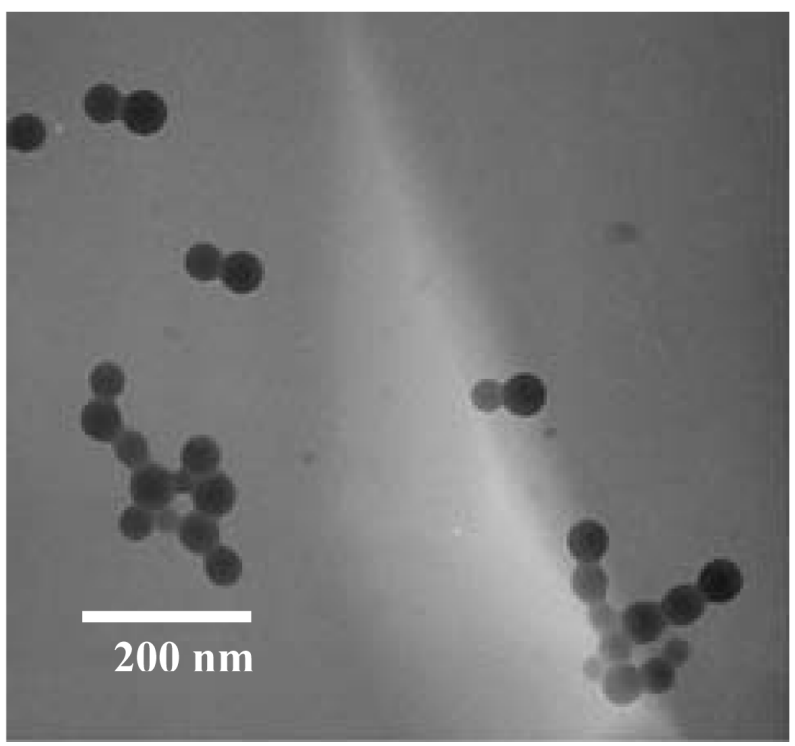

Figure 1. Scanning electron microscopy of chitosan nanoparticles (CNPs).

Table 1. Effect of chitosan nanoparticles (CNPs) and Quercetin (Q) on the liver enzymes and serum tumor markers in rats treated with $\mathrm{CCl}_{4}$.

\begin{tabular}{|c|c|c|c|c|c|}
\hline $\begin{array}{l}\text { Parameter } \\
\text { Groups }\end{array}$ & $\begin{array}{c}\text { AST } \\
(\mathrm{U} / \mathrm{L})\end{array}$ & $\begin{array}{l}\text { ALT } \\
\text { (U/L) }\end{array}$ & $\begin{array}{l}\text { ALP } \\
\text { (U/L) }\end{array}$ & $\begin{array}{l}\text { CEA } \\
\text { (ng/ml) }\end{array}$ & $\begin{array}{c}\mathrm{AFP} \\
(\mathrm{ng} / \mathrm{ml})\end{array}$ \\
\hline Control & $63.71 \pm 1.48^{\mathrm{a}}$ & $67.29 \pm 2.49^{\mathrm{a}}$ & $155.86 \pm 2.76^{\mathrm{a}}$ & $12.78 \pm 1.09^{\mathrm{a}}$ & $6.14 \pm 1.17^{\mathrm{a}}$ \\
\hline $\mathrm{CCl}_{4}$ & $94.29 \pm 2.15^{\mathrm{d}}$ & $212.57 \pm 5.11^{c}$ & $188.71 \pm 1.04^{\mathrm{d}}$ & $24.47 \pm 1.13^{\mathrm{d}}$ & $12.16 \pm 0.28^{c}$ \\
\hline CNPs-LD & $61.00 \pm 2.73^{\mathrm{a}}$ & $64.43 \pm 3.59^{\mathrm{a}}$ & $151.57 \pm 2.26^{\mathrm{b}}$ & $5.15 \pm 0.70^{\mathrm{b}}$ & $5.14 \pm 0.91^{\mathrm{a}}$ \\
\hline CNPs-HD & $57.43 \pm 1.56^{\mathrm{a}}$ & $65.14 \pm 3.71^{\mathrm{a}}$ & $155.29 \pm 2.86^{\mathrm{b}}$ & $5.19 \pm 0.83^{b}$ & $5.46 \pm 0.42^{\mathrm{a}}$ \\
\hline $\mathrm{Q}$ & $59.43 \pm 0.75^{\mathrm{a}}$ & $70.57 \pm 4.59^{\mathrm{a}}$ & $153.71 \pm 2 \cdot 00^{\mathrm{a}}$ & $5.49 \pm 0.93^{\mathrm{b}}$ & $5.60 \pm 1.00^{\mathrm{a}}$ \\
\hline CNPs-LD + Q & $64.71 \pm 1.19^{\mathrm{a}}$ & $70.29 \pm 4.08^{\mathrm{a}}$ & $158.86 \pm 1.99^{\mathrm{a}}$ & $3.91 \pm 0.59^{c}$ & $5.57 \pm 0.90^{\mathrm{a}}$ \\
\hline CNPs-HD + Q & $56.57 \pm 1.84^{\mathrm{a}}$ & $70.71 \pm 2.87^{\mathrm{a}}$ & $153.43 \pm 3.57^{\mathrm{a}}$ & $4.30 \pm 0.38^{\mathrm{c}}$ & $5.07 \pm 0.9^{\mathrm{a}}$ \\
\hline CNPs-LD $+\mathrm{CCl}_{4}$ & $79.50 \pm 0.56^{\mathrm{e}}$ & $88.5 \pm 3.80^{\mathrm{d}}$ & $150.00 \pm 1.51^{\mathrm{e}}$ & $13.45 \pm 0.95^{\mathrm{a}}$ & $2.74 \pm 0.65^{\mathrm{d}}$ \\
\hline CNPs-HD $+\mathrm{CCl}_{4}$ & $76.75 \pm 0.84^{\mathrm{e}}$ & $73.63 \pm 3.68^{\mathrm{e}}$ & $161.38 \pm 1.85^{\mathrm{a}}$ & $6.37 \pm 2.14^{\mathrm{b}}$ & $1.82 \pm 0.33^{\mathrm{e}}$ \\
\hline $\mathrm{Q}+\mathrm{CCl}_{4}$ & $76.80 \pm 1.46^{\mathrm{e}}$ & $68.8 \pm 2.92^{\mathrm{a}}$ & $165.00 \pm 1.64^{\mathrm{f}}$ & $5.35 \pm 1.05^{\mathrm{b}}$ & $2.41 \pm 0.37^{\mathrm{d}}$ \\
\hline CNPs-LD + Q + $\mathrm{CCl}_{4}$ & $73.56 \pm 0.82^{\mathrm{e}}$ & $67.78 \pm 3.50^{\mathrm{a}}$ & $146.00 \pm 2.55^{\mathrm{b}}$ & $6.37 \pm 0.86^{\mathrm{b}}$ & $2.74 \pm 0.45^{\mathrm{d}}$ \\
\hline CNPs-HD $+\mathrm{Q}+\mathrm{CCl}_{4}$ & $60.86 \pm 1.24^{\mathrm{a}}$ & $69.14 \pm 2.91^{\mathrm{a}}$ & $160.29 \pm 1.34^{\mathrm{a}}$ & $5.81 \pm 0.56^{\mathrm{b}}$ & $3.00 \pm 0.45^{\mathrm{b}}$ \\
\hline
\end{tabular}

Within each column, means superscript with different letter are significantly different $(\mathrm{P} \leq 0.05)$. Data presented as means $\pm \mathrm{SE}$. CNPs-LD: low dose of chitosan nanoparticles. CNPs-HD: high dose of chitosan nanoparticles.

nounced in the animals treated with $\mathrm{CCl}_{4}$ plus CNPs-HD, but least pronounced in the animals treated with $\mathrm{CCl}_{4}$ plus Q and CNPs-HD (Table 1).

The current study revealed that animals treated with $\mathrm{CCl}_{4}$ alone showed a significant decrease in hepatic GPx, SOD and catalase accompanied with a significant increase in MDA. However, animals treated with Q and/or CNPs at the two tested doses showed a significant increase in the level of hepatic GPx, catalase and SOD and did not affect MDA level compared to the control group (Table 2). This increase $\mathrm{n}$ the antioxidant parameters was more prounanced in the groups received the combined treatment with Q plus CNPs at the two doses. The combined treatment with $\mathrm{CCl}_{4}$ plus Q and CNPs-LD or CNPs-HD resulted in a significant improvement in the 
Table 2. Effect of chitosan nanoparticles (CNPs) and Quercetin (Q) on antioxidant enzymes and MDA in rat treated with $\mathrm{CCl}_{4}$.

\begin{tabular}{ccccc}
\hline $\begin{array}{c}\text { Parameter } \\
\text { Groups }\end{array}$ & $\begin{array}{c}\text { GPx } \\
\text { (unit/mg protein) }\end{array}$ & $\begin{array}{c}\text { SOD } \\
\text { (unit/mg protein) }\end{array}$ & $\begin{array}{c}\text { Catalase } \\
\text { (unit/mg protein) }\end{array}$ & $\begin{array}{c}\text { MDA } \\
\text { (nmol/g tissue) }\end{array}$ \\
\hline Control & $283.42 \pm 11.11^{\mathrm{a}}$ & $255.21 \pm 12.60^{\mathrm{a}}$ & $3.55 \pm 0.13^{\mathrm{a}}$ & $109.02 \pm 2.20^{\mathrm{a}}$ \\
$\mathrm{CCl}_{4}$ & $174.72 \pm 12.00^{\mathrm{f}}$ & $118.75 \pm 13.54^{\mathrm{c}}$ & $1.64 \pm 0.11^{\mathrm{c}}$ & $148.37 \pm 1.96^{\mathrm{b}}$ \\
CNPs-LD & $451.67 \pm 20.20^{\mathrm{b}}$ & $266.52 \pm 12.79^{\mathrm{a}}$ & $4.85 \pm 0.02^{\mathrm{b}}$ & $111.97 \pm 1.30^{\mathrm{a}}$ \\
CNPs-HD & $778.14 \pm 42.45^{\mathrm{c}}$ & $344.20 \pm 13.37^{\mathrm{b}}$ & $4.84 \pm 0.09^{\mathrm{b}}$ & $116.56 \pm 0.42^{\mathrm{a}}$ \\
Q & $389.07 \pm 42.45^{\mathrm{d}}$ & $340.18 \pm 14.89^{\mathrm{b}}$ & $4.95 \pm 0.20^{\mathrm{b}}$ & $105.73 \pm 1.36^{\mathrm{a}}$ \\
CNPs-LD + Q & $691.41 \pm 36.77^{\mathrm{e}}$ & $349.22 \pm 16.80^{\mathrm{b}}$ & $4.95 \pm 0.10^{\mathrm{b}}$ & $106.19 \pm 0.77^{\mathrm{a}}$ \\
CNPs-HD + Q & $629.3 \pm 19.11^{\mathrm{e}}$ & $357.59 \pm 23.79^{\mathrm{b}}$ & $4.96 \pm 0.10^{\mathrm{b}}$ & $105.86 \pm 1.22^{\mathrm{a}}$ \\
CNPs-LD + CCl & $445.66 \pm 18.87^{\mathrm{b}}$ & $352.73 \pm 14.32^{\mathrm{b}}$ & $4.51 \pm 0.40^{\mathrm{b}}$ & $119.24 \pm 2.06^{\mathrm{c}}$ \\
CNPs-HD + CCl & $513.44 \pm 38.30^{\mathrm{g}}$ & $362.5 \pm 10.98^{\mathrm{b}}$ & $4.85 \pm 0.01^{\mathrm{b}}$ & $122.03 \pm 1.22^{\mathrm{c}}$ \\
Q + CCl & $453.91 \pm 41.01^{\mathrm{b}}$ & $354.38 \pm 10.88^{\mathrm{b}}$ & $4.96 \pm 0.20^{\mathrm{b}}$ & $120.15 \pm 1.94^{\mathrm{c}}$ \\
CNPs-LD + Q + CCl & $529.71 \pm 23.59^{\mathrm{g}}$ & $355.21 \pm 12.44^{\mathrm{b}}$ & $4.93 \pm 0.20^{\mathrm{b}}$ & $115.89 \pm 6.83^{\mathrm{a}}$ \\
CNPs-HD + Q + CCl & $738.16 \pm 21.97^{\mathrm{c}}$ & $354.69 \pm 11.56^{\mathrm{b}}$ & $4.94 \pm 0.21^{\mathrm{b}}$ & $95.36 \pm 1.82^{\mathrm{d}}$ \\
\hline
\end{tabular}

Within each column, means superscript with different letter are significantly different $(\mathrm{P} \leq 0.05)$. Data presented as means \pm SE. CNPs-LD: low dose of chitosan nanoparticles. CNPs-HD: high dose of chitosan nanoparticles.

antioxidant enzyme activities and MDA level toward the control level.

The hepatic MDA level in group treated with Q and/or CNPs at the two tested doses were comparable to the control group. Treatment with CNPs at the low dose plus quercetin effectively normalized the level of hepatic MDA in groups treated with $\mathrm{CCl}_{4}$. On the other hand, treatment with the high dose of CNPs plus quercetin resulted in a significant increase in hepatic MDA compared to the control group in $\mathrm{CCl}_{4}$-treated animals. Although the single treatment with quercetin or nanochitosan at the two tested doses in animals treated with $\mathrm{CCl}_{4}$ resulted in a significant increase in the level of hepatic MDA towards the control value, it did not normalize the level of hepatic MDA (Table 2). This improvement was more pronounced in the group treated with Q plus CNPs-HD.

The biochemical results of the current study were further confirmed by the histological examination of the liver tissue. The microscopic examination of the control group and those treated with CNPs-LD, CNPs-HD, Q, CNPs-LD plus Q or CNPs-HD plus Q showed normal lobular architecture with central veins and radiating hepatic cords (Figure 2(a)). The liver of animals treated with $\mathrm{CCl}_{4}$ alone showed severe pathological changes included multi focal of fibrosis and cirrhosis together with extensive centrilobular necrosis, cell death, ballooning, thickening in blood vessels, fatty droplets, lymphocytes inflammation, bile ducts proliferation and dense fibrous tissue were well marked (Figures 2(b)-(d)). The liver of animals treated with $\mathrm{CCl}_{4}$ plus CNPs-LD (Figure 3(a)), CNPs-HD (Figure 3(b)), Q (Figure 3(c)), CNPs-LD plus Q (Figure 3(d)) or CNPs-HD plus Q (Figure 3(e)) showed marked decrease in hepatocytes degenerative changes induced by $\mathrm{CCl}_{4}$. There are featuers of mitotic cells and marked decrease in collagen fibril, steatosis and inflammation, the improvements in hepatocytes morphology are clarify around the center vein than that in portal vein.

Masson's trichrome stained tissues of control rats showed no fibrosis and a fine liner of collagen around the central vein (Figure 4(a)). The liver sections of animals treated with $\mathrm{CCl}_{4}$ alone showed the fibrous septa and cirrhosis as a bundle of collagen fibrils extended from the central vein and portal tract and dissecting the parenchyma (Figure 4(b)). The liver section in rats treated with CNPs-LD, CNPs-HD, Q, CNPs-LD plus Q or CNPsHD plus Q showed moderate amount of fibrosis and collagen around the portal area (Figure 4(c)). However, the liver sections in the animals treated with $\mathrm{CCl}_{4}$ plus $\mathrm{Q}$ or CNPs at the two tested doses alone or in combination showed a reduction in collagen fibers and inflammatory cells (Figure 4(d))

The image analysis (Figure 5) indicated a significant increase in area percentage of collagen fibers in the group treated with $\mathrm{CCL}_{4}$ alone compared to the control group. Whereas, a significant improvement in hepatic parenchyma and a marked decreased in connective tissues and collagen fibers were observed in the groups 


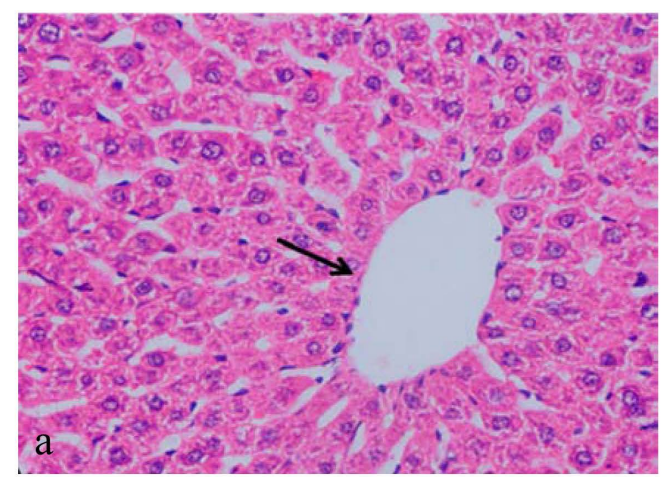

$(\mathrm{Hx} \& \mathrm{E} X 400)$

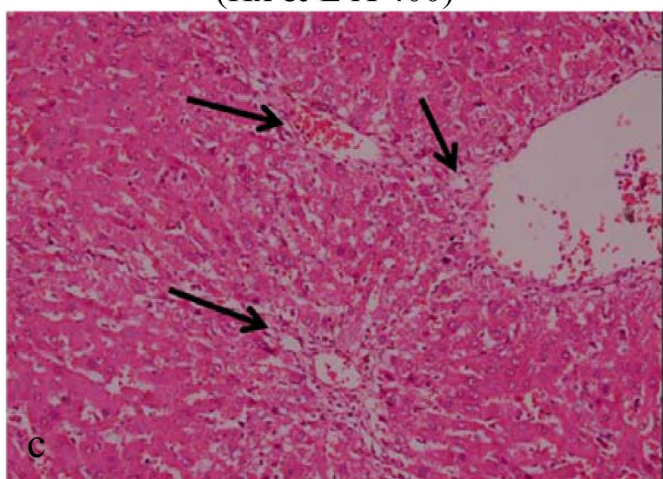

$(\mathrm{Hx} \& \mathrm{E} X 300)$

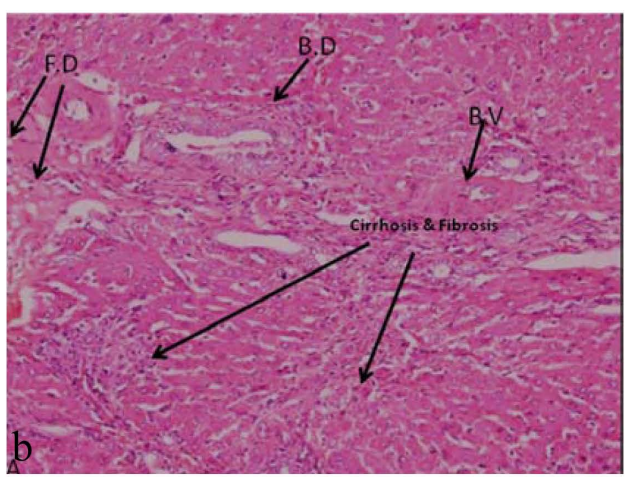

$(\mathrm{Hx} \& \mathrm{E} X 300)$

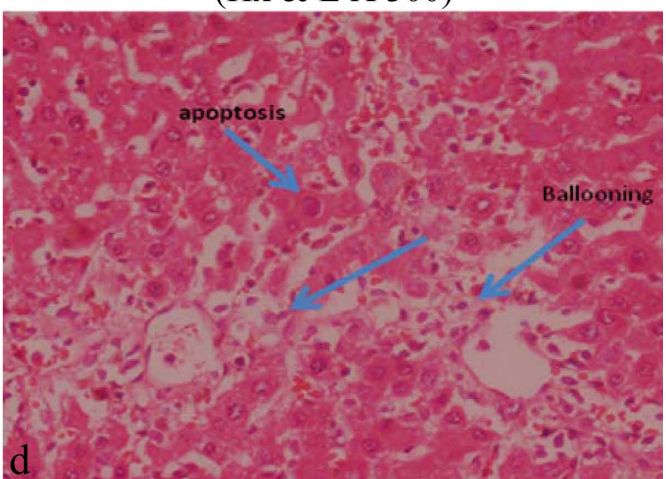

(Hx \& E X 400)

Figure 2. Photomicrographs of liver sections of (a) the control group and those treated with CNPs-LD, CNPs-HD, Q, CNPsLD plus Q or CNPs-HD plus Q showing normal histological appearance, (b, c) the group treated with $\mathrm{CCl}_{4}$ alone showing marked fibrosis and cirrhosis together with extensive centrilobular necrosis, cell death, ballooning, thickening in blood vessels, fatty droplets, lymphocytes inflammation and bile ducts proliferation, (d) High magnification of the liver section in rats treated with $\mathrm{CCl}_{4}$ alone showing cellular apoptosis and ballooning damage. (Q: Quercetin; CNPs-LD: chitosan nanoparticlelow dose; CNPs-HD: chitosan nanoparticle-high dose).

treated with $\mathrm{CCl}_{4}$ plus Q or CNPs at the two tested doses alone or in combination. On the other hand, no significant differences were observed between the control group and the groups treated with Q, Q plus CNPs-LD, Q plus CNPs-HD and Q plus $\mathrm{CCl}_{4}$ (Figure 5).

\section{Discussion}

The characterization of chitosan showed that it has low molecular weight with high degree of deacetylation. This resulted in an increase of positive charges due to free amino groups and consequently facilitates the coupling process with other molecules such as quercetin. The in vivo study revealed that the protective role of chitosan nanoparticle alone or in combination with quercetin against oxidative stress and hepatotoxicity induced by carbon tetrachloride in rat model was evaluated. The selected doses of $\mathrm{CCl}_{4}$, chitosan nanoparticles and quercetin were literature based [68]-[70], respectively). In the current study, treatment with $\mathrm{CCl}_{4}$ induced severe hepatotoxicity and oxidative stress as well as histological changes typical to those reported in the literature. Animals treated with $\mathrm{CCl}_{4}$ showed a significant increase in liver function enzymes (ALT, AST and ALP), tumor markers (CEA and AFP) and oxidative stress markers (MDA) accompanied with a significant decrease in antioxidant enzymes (GPx, SOD and catalase) in liver tissue. Elevation of ALT and AST reflects generalized damage to hepatocytes while elevation of ALP reflects cholestasis [71]. The elevated levels of ALT, AST, ALP reported in the current study in animals treated with $\mathrm{CCl}_{4}$, indicated severe hepatic parenchymal cell injury and were in agreement with the previous reports [72]-[75]. Moreover, $\mathrm{CCl}_{4}$ was found to induce oxidative stress in hepatic tissue leading to accumulation of free radicals and consequently decreased activities of hepatic antioxidant enzymes; SOD, CAT and GPx with increased level of MDA indicating the oxidative damage to the hepatic tissue caused by $\mathrm{CCl}_{4}[76]-[78]$. 

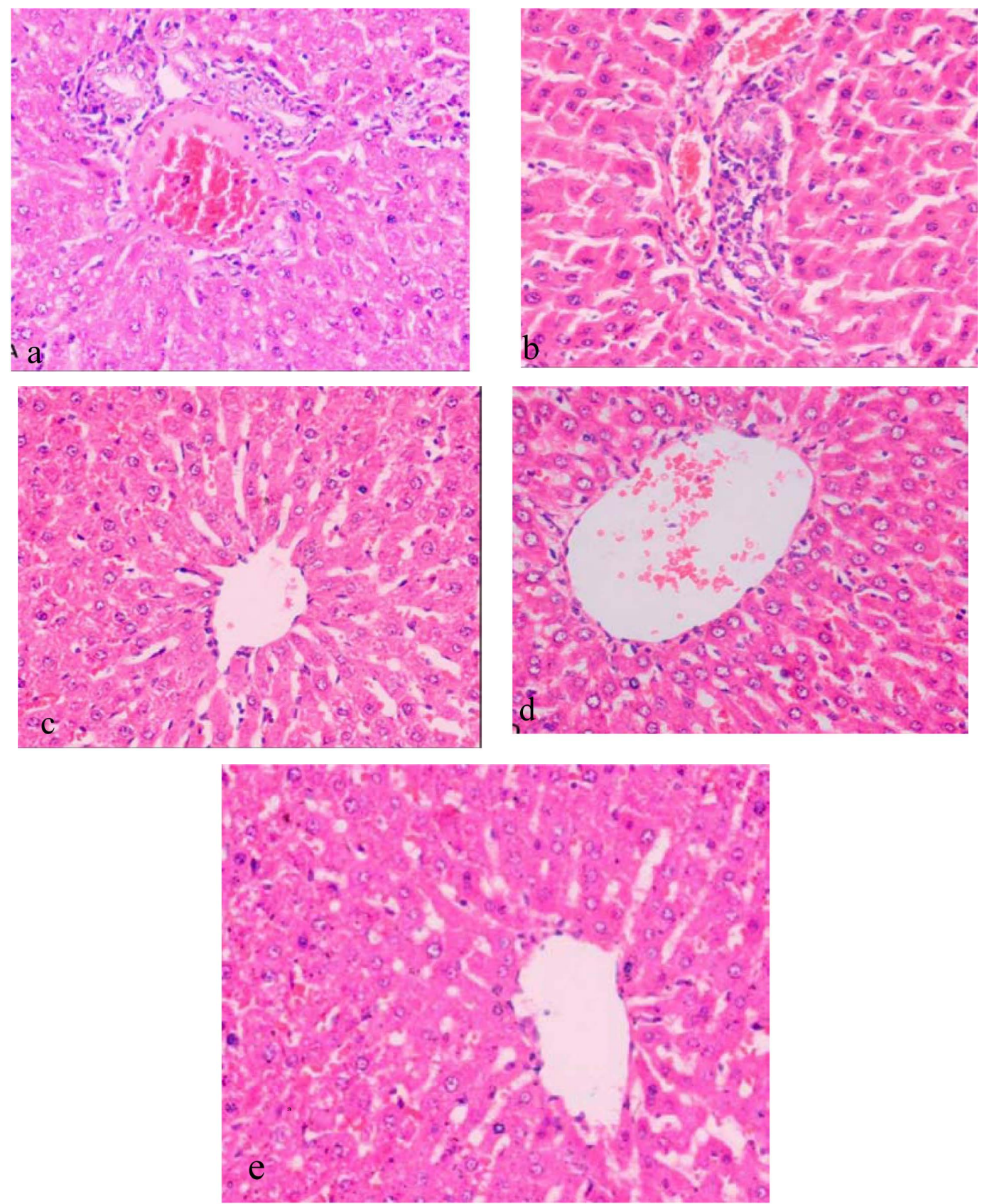

Figure 3. Photomicrographs of liver sections of (a) the group treated with $\mathrm{CCl}_{4}$ plus NC-LD; (b) the group treated with $\mathrm{CCl}_{4}$ plus NC-HD; (c) the group treated with $\mathrm{CCl}_{4}$ plus Q; (d) the group treated with $\mathrm{CCl}_{4}$ plus CNPs-LD and Q and (e) of the group treated with $\mathrm{CCl}_{4}$ plus CNPs-HD and $\mathrm{Q}$, showing marked decrease in hepatocytes degenerative changes induced by $\mathrm{CCl}_{4}$. There are features of mitotic cells and marked decrease in collagen fibril, steatosis and inflammation, the improvement in hepatocytes morphology is clarify around the center vein than that in portal vein. Q: Quercetin; CNPs-LD: chitosan nanoparticle-low dose; CNPs-HD: chitosan nanoparticle-high dose) $(\mathrm{H} \times \& \mathrm{E} \times 400)$.

Carcinoembryonic antigen (CEA) is considered specific biomarkers for liver cancer. Therefore, elevated serum CEA level reported herein is associated with liver metastasis [79]. Input of CEA into the circulation is controlled by production rate of the tumor; its location and stage, its size, differentiation and vascularity and the presence or absence of distant metastases [80] [81]. However, alpha feto protein (AFP) is the principal in fetal plasma in early gestation is subsequently present at very low levels $(<25 \mathrm{mg} / \mathrm{L})$. It increases in hepatocellular carcinoma (HCC) and other liver diseases like chronic hepatitis, in regeneration phase of acute hepatitis and in 


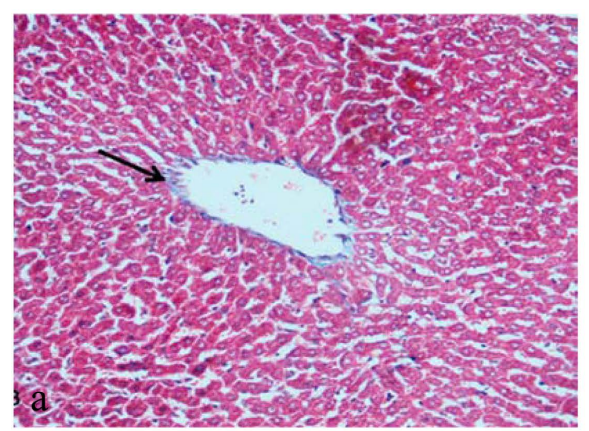

(Masson's trichrome X 200)

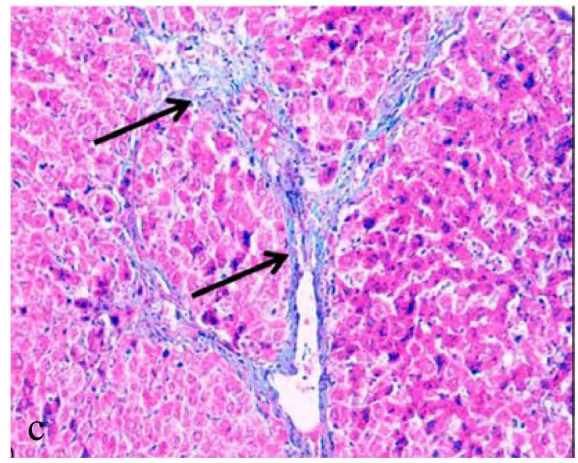

(Masson's trichrome reaction X300)

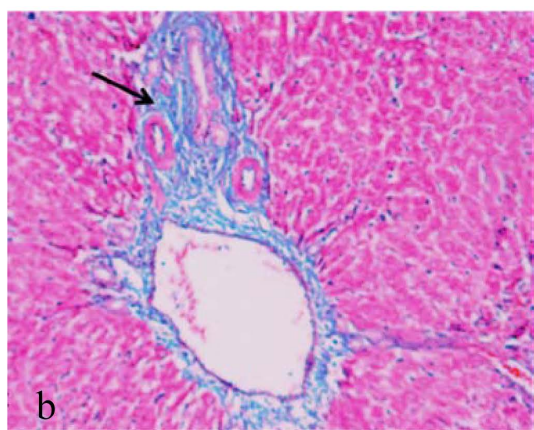

(Masson's trichrome X200)

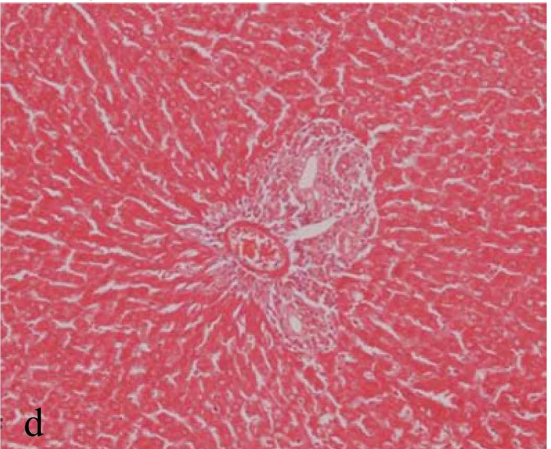

(Masson's trichrome reaction X300)

Figure 4. Photomicrographs of liver sections of (a) control rats showing no fibrosis investigated and a fine liner of collagen around the central vein; (b) rats treated with CNPs-LD, CNPs-HD, Q, CNPs-LD + Q or CNPs-HD + Q showing moderate amount of fibrosis and collagen around the portal area; (c) rats treated with $\mathrm{CCl}_{4}$ alone showing the fibrous septa and cirrhosis are investigated as a bundle of collagen fibrils extended from the central vein and portal tract and dissecting the parenchyma and (d) rats treated with $\mathrm{CCl}_{4}$ plus CNPs-LD, $\mathrm{CCl}_{4}$ plus CNPs- $\mathrm{HD}, \mathrm{CCl}_{4}$ plus Q, $\mathrm{CCl}_{4}$ plus $\mathrm{CNPs}-\mathrm{LD}$ and $\mathrm{Q}$ and $\mathrm{CCl}{ }_{4}$ plus CNPs-HD and Q showing a reduction in collagen fibers and inflammatory cells. (Q: Quercetin; CNPs-LD: chitosan nanoparticle-low dose; CNPs-HD: chitosan nanoparticle-high dose).

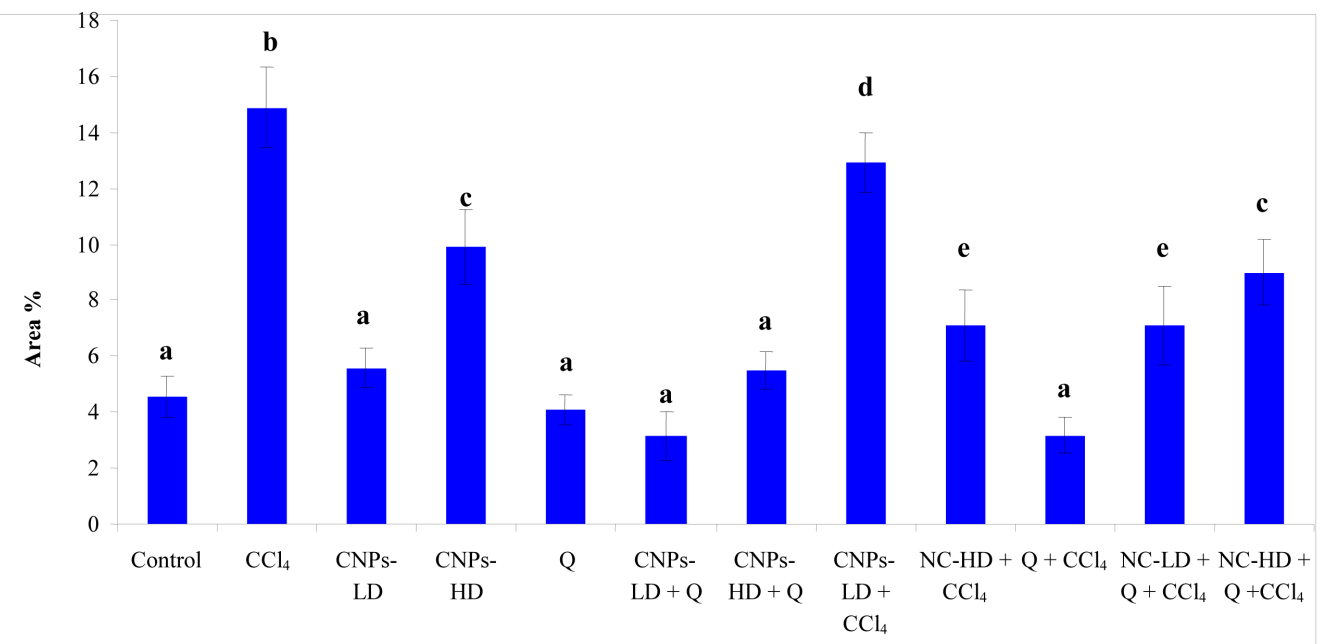

Figure 5. Effect of different treatments on the area percentage of collagen in liver tissues.

hepatic metastasis [82]. The elevated levels of CEA and AFP reported in the current study after the administration of $\mathrm{CCl}_{4}$ were indicative of liver injury and alteration of tumor response by $\mathrm{CCl}_{4}$ and were in accordance with the results of previous reports [83] [84]. Lipid peroxidation (LP) is one of the main manifestations of oxid- 
ative damage and it has been found to play an important role in the toxicity and carcinogenicity. The increase in hepatic MDA level reported in the current study revealed the increase in LP resulting in tissue damage and failure of the antioxidant defense mechanisms to prevent the formation of excessive free radicals [73] [84]-[86]. The biochemical results of the current study were further confirmed by the histopathological study which showed that liver tissue more or less have significant changes in the histological pictures in $\mathrm{CCl}_{4}$-intoxicated rats typical to those reported in the literature [73] [84] [87].

As a solution for the water-insolubility problem of chitosan, nanoparticle formulation provides a plausible pharmaceutical basis for enhancing oral bioavailability and therapeutic efficacy of chitosan and other drugs that are poorly soluble [26]. In addition, nanoparticles possess a stronger curvature of the surface, compared to large particles; this produces more dissolution pressure with a corresponding increase in saturation solubility [27]. The increased saturation solubility, in turn, favors an increase in concentration gradient between intestinal epithelial cells and the mesenteric circulation beneath. Consequently, chitosan nanoparticles (CNPs) could exhibit more superior activities than chitosan due to their small size and quantum size effect. Not surprisingly, CNPs have been reported to have heightened immune-enhancing effect [88], anticancer activity [89], antimutagenic activity [90] and antimicrobial activity [91] than those of CS. Nevertheless, other biological activities are unknown, such as the antioxidant activity of CNPs, which has received less attention. In the present study, animals treated with $\mathrm{CCl}_{4}$ plus CNPs at the two tested doses showed significant improvements in the hepatic toxicity biomarkers, antioxidant enzymes, oxidative stress markers, tumor markers as well as the significant improvement in the histological picture of the liver. These findings are in harmony with the findings of Wen et al. [92] who reported a protective role of CNPs with a mean diameter of $83.66 \mathrm{~nm}$ against $\mathrm{H}_{2} \mathrm{O}_{2}$-induced RAW-264.7 cell injury through restoring the activities of endogenous antioxidants (SOD, GPx and CAT), along with enhancement of their gene expression.

Although no scientific report has been published so far describing the protective role of CNPs against $\mathrm{CCL}_{4}$ induced hepatotoxicity and oxidative stress in liver tissues, the hepatoprotective effect of chitosan has been documented in several reports; for instance, Jeon et al. [93] investigated the antioxidative effect of chitosan on chronic $\mathrm{CCl}_{4}$-induced hepatic injury in rats and showed that chitosan has strong antioxidative effects, which decrease TBARS production and increase antioxidant enzyme (catalase and SOD) activities during chronic $\mathrm{CCl}_{4}$ induced lipid peroxidation. In the same concern, Subhapradha et al. [94] reported the hepatoprotective effect of $\beta$-Chitosan from Gladius of Sepioteuthis lessoniana against $\mathrm{CCl}_{4}$-induced oxidative stress in rats. These authors showed that, in addition to normalizing the oxidative stress markers, which is attributed to the antoxidant properties of chitosan, the normalization of plasma AST and ALT levels in $\beta$-chitosan and $\mathrm{CCl}_{4}$-treated rats indicates that $\beta$-chitosan may stabilize the cell membrane and may prevent a leakage of intracellular enzymes into the blood. Thus, the overall hepatoprotective effect of chitosan is probably due to a counteraction of free radicals by its antioxidant nature and/or to its ability to inhibit lipid accumulation by its antilipidemic property [95] [96]. Santhosh et al. [97] showed that co-treatment with chitosan may prevent antitubercular drugs-induced hepatotoxicity in rats. Moreover, chitosan was also effective against TCDD-induced hepatotoxicity which is persistent and highly toxic environmental pollutants [98]. Furthermore, chitosan was proved to be hepatoprotective against oxidative damage induced by radiotherapy [99].

In the current study, treatment with quercetin and CNPs at the two tested doses succeeded to improve the antioxidant capacity of the body and reduce the oxidative stress as indicated by the increase in antioxidant enzymes (CAT, SOD, GPx) and decrease of MDA levels. Treatment with quercetin plus CNPs to the intoxicated rats could markedly suppress the high serum level of liver biochemical parameters (ALT, AST, ALP) as well as decrease the increased levels of tumor markers (AFP and CEA). Moreover, these protective agents succeeded to improve the histological changes resulted in liver tissue of $\mathrm{CCl}_{4}$-treated rats. The hepatoprotective and antioxidant properties of quercetin are supported by the findings of Pavanato et al. [100] who found that administration of quercetin to rats significantly improved all the hepatic toxicity biomarkers in $\mathrm{CCl}_{4}$-induced liver fibrosis in addition to improve liver histology. In the same concern, Pilkhwal et al. [101] showed that quercetin attenuated LPS-induced hepatotoxicity and oxidative stress. On the other hand, Kebieche et al. [102] reported that quercetin ameliorated the altered enzyme levels and protected rat liver against chemicals- or drugs-induced hepatotoxicity and Utesch et al. [58] demonstrated that quercetin administration did induce any genotoxic effects in vivo following oral exposure. Padma et al. [103] investigated the protective effect of quercetin against lindane-induced hepatotoxicity and suggested that the protective effect of quercetin on oxidative damage was attributable to its free radical scavenging action and antioxidant nature. Furthermore, Abo-Salem et al. [104] showed that 
treatment with quercetin decreased the acrylonitrile-induced elevation in biochemical parameters and was effective in structural improvement of liver. Moreover, Nabavi et al. [105] showed that the administration of quercetin prior to sodium fluoride intoxication prevents hepatotoxicity and oxidative stress in rat liver, probably because of its antioxidant effect. Furthermore, the recent study by Tang et al. [106] showed quercetin dose dependently induced HO-1(rate-limiting enzymes of heme catabolism), HO-1 upregulation may limit the CYP2E1 induction by ethanol through depleting heme pool. Moreover, HO-1 metabolite CO mediated the beneficial effect of quercetin against ethanol hepatotoxicity through directly inactivating CYP2E1. It is of interest to mention that beside the protective role of CNPs alone, it enhanced the antioxidant effect of quercetin and overcome the problem associated with the poor absorption and bioavailability of quercetin upon oral administration suggested that it is a good candidate as drug delivery.

In this concern, Torresa et al. [107] synthesized chitosan-flavonoid conjugate by covalent enzymatic chitosan modification with quercetin; the quercetin-modified chitosan to enhancement of the antioxidant and antimicrobial properties and retained thermal degradability. As for safety, although nanonization is an effective method to improve the bioavailabitity of chitosan and enhance its antioxidant effects, attention should be paid concerning the particle size; i.e. nanoparticles that are extremely minute in size can disrupt the normal function of the basic biological structures.

\section{Conclusion}

It could be concluded that the both CNPs and quercetin succeeded to induce hepatoprotection against $\mathrm{CCl}_{4}$-induced toxicity. Hepatoprotection occurred in a dose-dependant fashion by CNPs. The combined treatment with quercetin plus the high dose of CNPs had the most effective antioxidative and protective effects against $\mathrm{CCl}_{4}{ }^{-}$ induced damage in liver.

\section{Conflict of Interest}

The authors declare that there are no conflicts of interest.

\section{Acknowledgements}

This work was supported by the National Research Centre, Dokki, Cairo, Egypt project \#10070112 and ANR "NanoSNO”, Faculty of Pharmacy, Lorraine University, Nancy Cedex, France.

\section{References}

[1] Choi, B.I., Takayasu, K. and Han, M.C. (993) Small Hepatocellular Carcinomas and Associatednodular Lesions of the Liver: Pathology, Pathogenesis, and Imaging Findings. American Journal of Roentgenology, 160, 1177-1187. http://dx.doi.org/10.2214/ajr.160.6.8388618

[2] Jemal, A., Bray, F., Center, M.M., Ferlay, J., Ward, E. and Forman, D. (2011) Global Cancer Statistics. CA Cancer Journal for Clinicians, 61, 69-90. http://dx.doi.org/10.3322/caac.20107

[3] El-Serag, H.B. (2011) Hepatocellular Carcinoma. New England Journal of Medicine 365, 1118-1127. http://dx.doi.org/10.1056/NEJMra1001683

[4] Forner, A., Hessheimer, A.J., Isabel, R.M. and Bruix, J. (2006) Treatment of Hepatocellular Carcinoma. Critical Reviews in Oncology/Hematology, 60, 89-98. http://dx.doi.org/10.1016/j.critrevonc.2006.06.001

[5] Xu, Y., Wen, Z. and Xu, Z. (2009) Chitosan Nanoparticles Inhibit the Growth of Human Hepatocellular Carcinoma Xenografts through an Antiangiogenic Mechanism. Anticancer Research, 29, 5103-5109.

[6] Agrawal, P., Strijkers, G.J. and Nicolay, K. (2010) Chitosan-Based Systems for Molecular Imaging. Advanced Drug Delivery Reviews, 62, 42-58. http://dx.doi.org/10.1016/j.addr.2009.09.007

[7] Santosh, K., Joonseok, K., Hyerim, K., Gupta, M.K. and Dutta, P.K. (2012) A New Chitosan Thymine Conjugates: Synthesis, Characterization and Biological Activity. International Journal of Biological Macromolecules, 50, 493-502. http://dx.doi.org/10.1016/j.ijbiomac.2012.01.015

[8] Ziwei, D., Zipeng, Z., Xiaoxi, H., Shuilin, W., Zushun, X. and Paul, K. (2011) Hollow Chitosan-Silica Nanospheres as pH-Sensitive Targeted Delivery Carriers in Breast Cancer Therapy. Biomaterial, 32, 4976-4986. http://dx.doi.org/10.1016/j.biomaterials.2011.03.050

[9] Jinghua, D., Yangde, Z., Shiwei, H., Yuxiang, C., Bo, L., Mingmei, L., Wei, C., Xingming, D. and Jinfeng, Z. (2010) 
Synthesis and in Vitro/in Vivo Anticancer Evaluation of Curcumin-Loaded Chitosan/Poly (Butyl Cyanoacrylate) Nanoparticles. International Journal of Pharmaceutics, 400, 211-220. http://dx.doi.org/10.1016/j.ijpharm.2010.08.033

[10] Jeon Y.J. and Kim, S.K. (2001) Potential Immuno-Stimulating Effect of Antitumoral Fraction of Chitosan Oligosaccharides. Journal of Chitin Chitosan, 6, 163-167.

[11] Vo, T.S., Kim, J.A., Ngo, D.H., Kong, C.S. and Kim, S.K. (2012) Protective Effect of Chitosan Oligosaccharides against FceRI-Mediated RBL-2H3 Mast Cell Activation. Process Biochemistry, 47, 327-330. http://dx.doi.org/10.1016/j.procbio.2011.10.036

[12] Gua, R.L., Sun, W.Z., Zhou, H., Wu, Z.N., Meng, Z.Y., Zhu, X.X., et al. (2010) The Performance of a Fly-Larva ShellDerived Chitosan Sponge as an Absorbable Surgical Hemostatic Agent. Biomaterials, 31, 1270-1277. http://dx.doi.org/10.1016/j.biomaterials.2009.10.023

[13] Wang, J.L., Hu, W., Liu, Q. and Zhang, S.M. (2011) Dual-Functional Composite with Anticoagulant and Antibacterial Properties Based on Heparinized Silk Fibroin and Chitosan. Colloids and Surfaces B: Biointerfaces, 85, 241-247. http://dx.doi.org/10.1016/j.colsurfb.2011.02.035

[14] Vikhoreva, G., Bannikova, G., Stolbushkina, P., Panov, A., Drozd, N., Makarov, V. and Gal’braikh, L. (2005) Preparation and Anticoagulant Activity of a Low-Molecular-Weight Sulfated Chitosan. Carbohydrate Polymers, 62, 327-332. http://dx.doi.org/10.1016/j.carbpol.2005.05.022

[15] Ormrod, D.J., Holmes, C.C. and Miller, T.E. (1998) Dietary Chitosan Inhibits Hypercholesterolaemia and Atherogenesis in the Apolipoprotein E-Deficient Mouse Model of Atherosclerosis. Atherosclerosis, 138, 329-334. http://dx.doi.org/10.1016/S0021-9150(98)00045-8

[16] Chung, M.J., Park, J.K. and Park, Y.I. (2012) Anti-Inflammatory Effects of Low-Molecular Weight Chitosan Oligosaccharides in IgE-Antigen Complex-Stimulated RBL-2H3 Cells and Asthma Model Mice. International Immunopharmacology, 12, 453-459. http://dx.doi.org/10.1016/j.intimp.2011.12.027

[17] Anraku, M., Kabashima, M., Namura, H., Maruyama, T., Otagiri, M., Gebicki, J.M. and Tomida, H. (2008) Antioxidant Protection of Human Serum Albumin by Chitosan. International Journal of Biological macromolecules, 43, 159164. http://dx.doi.org/10.1016/j.ijbiomac.2008.04.006

[18] Park, P.J., Je, J.Y., Byun, H.G., Moon, S.H. and Kim, S.K. (2004) Antimicrobial Activity of Hetero-Chitosans and Their Oligosaccharides with Different Molecular Weights. Molecular Microbiology and Biotechnology, 14, 317-323.

[19] Yang, T.C., Chou, C.C. and Li, C.F. (2005) Antibacterial Activity of N-Alkylated Disaccharide Chitosan Derivatives. International Journal of Food Microbiology, 97, 237-245. http://dx.doi.org/10.1016/S0168-1605(03)00083-7

[20] Sun, Y., Liu, Y., Li, Y.Z., Lv, M.Z., Li, P.W., Xu, H.L. and Wang, L. (2011) Preparation and Characterization of Novel Curdlan/Chitosan Blending Membranes for Antibacterial Applications. Carbohydrate Polymers, 84, 952-959. http://dx.doi.org/10.1016/j.carbpol.2010.12.055

[21] Jayakumar, R., Prabaharan, M., Sudheesh Kumar, P.T., Nair, S.V. and Tamura, H. (2011) Biomaterials Based on Chitin and Chitosan in Wound Dressing Applications. Biotechnology Advances, 29, 322-337. http://dx.doi.org/10.1016/j.biotechadv.2011.01.005

[22] Wang, T., Zhu, X.K., Xue, X.T. and Wu, D.Y. (2012) Hydrogel Sheets of Chitosan, Honey and Gelatin as Burn Wound Dressings. Carbohydrate Polymers, 88, 75-83. http://dx.doi.org/10.1016/j.carbpol.2011.11.069

[23] Qin, Y.K., Xing, R.G., Liu, S., Li, K.C., Meng, X.T., Li, R.F., Cui, J.H., Li, B. and Li, P.C. (2012) Novel Thiosemicarbazone Chitosan Derivatives: Preparation, Characterization, and Antifungal Activity. Carbohydrate Polymers, 87, 2664-2670. http://dx.doi.org/10.1016/j.carbpol.2011.11.048

[24] Martínez-Camacho, A.P., Cortez-Rocha, M.O., Ezquerra-Brauer, J.M., Graciano-Verdugo, A.Z., Rodriguez-Félix, F., Castillo-Ortega, M.M. and Plascencia-Jatomea, M. (2010) Chitosan Composite Films: Thermal, Structural, Mechanical and Antifungal Properties. Carbohydrate Polymers, 82, 305-315. http://dx.doi.org/10.1016/j.carbpol.2010.04.069

[25] Ai, H., Wang, F.R., Xia, Y.Q., Chen, X.M. and Lei, C.L. (2012) Antioxidant, Antifungal and Antiviral Activities of Chitosan from the Larvae of Housefly, Musca domestica L. Food Chemistry, 132, 493-498. http://dx.doi.org/10.1016/j.foodchem.2011.11.033

[26] Lee, J. (2005) Nanoparticle Formulation Increases Oral Bioavailability of Poorly Soluble Drugs: Approaches Experimental Evidences and Theory. Current Nanoscience, 1, 237-243. http://dx.doi.org/10.2174/157341305774642939

[27] Patel, V.R. and Agrawal, Y.K. (2011) Nanosuspension: An Approach to Enhance Solubility of Drugs. Journal of Advanced Pharmaceutical Technology and Research, 2, 81-87. http://dx.doi.org/10.4103/2231-4040.82950

[28] Manach, C., Scalbert, A., Morand, C., Rémésy, C. and Jiménez, L. (2004) Polyphenols: Food Sources and Bioavailability. American Journal of Clinical Nutrition, 79, 727-747.

[29] Moon, Y.J., Wang, X. and Morris, M.E. (2006) Dietary Flavonoids: Effects on Xenobiotic and Carcinogen Metabolism. Toxicology in Vitro, 20, 187-210. http://dx.doi.org/10.1016/j.tiv.2005.06.048

[30] Dajas, F. (2012) Life or Death: Neuroprotective and Anticancer Effects of Quercetin. Journal of Ethnopharmacology, 
143, 383-396. http://dx.doi.org/10.1016/j.jep.2012.07.005

[31] Russo, G.L., Russo, M., Spagnuolo, C, Tedesco, I., Bilotto, S., Iannitti, R. and Palumbo, R. (2014) Quercetin: A Pleiotropic Kinase Inhibitor against Cancer. Advances in Nutrition \& Cancer, 159, 185-205.

[32] Horton, J.A., Li, F., Chung, E.J., Hudak, K., White, A., Krausz, K. and Citrin, D. (2013) Quercetin Inhibit SradiationInduced Skin Fibrosis. Radiation Research, 180, 205-215. http://dx.doi.org/10.1667/RR3237.1

[33] Hernández-Ortega, L.D., Alcántar-Díaz, B.E., Ruiz-Corro, L.A., Sandoval-Rodriguez, A., Bueno-Topete, M., Armendariz-Borunda, J. and Salazar-Montes, A.M. (2012) Quercetin Improves Hepatic Fibrosis Reducing Hepatic Stellate Cells and Regulating Profibrogenic/Anti-Fibrogenic Molecules Balance. Journal of Gastroenterology \& Hepatology, 27, 1865-1872. http://dx.doi.org/10.1111/j.1440-1746.2012.07262.x

[34] Yu, P.X., Zhou, Q.J., Zhu, W.W., Wu, Y.H., Wu, L.C., Lin, X. and Qiu, B.T. (2013) Effects of Quercetin on LPS-Induced Disseminated Intravascular Coagulation (DIC) in Rabbits. Thrombosis Research, 131, e270-e273. http://dx.doi.org/10.1016/j.thromres.2013.03.002

[35] Hirai, I., Okuno, M., Katsuma, R., Arita, N., Tachibana, M. and Yamamoto, Y. (2010) Characterisation of Anti-Staphylococcus aureus Activity of Quercetin. International Journal of Food Science Technology, 45, 1250-1254. http://dx.doi.org/10.1111/j.1365-2621.2010.02267.x

[36] Pashevin, D.A., Tumanovska, L.V., Dosenko, V.E., Nagibin, V.S., Gurianova, V.L. and Moibenko, A.A. (2011) Antiatherogenic Effect of Quercetin Is Mediated by Proteasome Inhibition in the Aorta and Circulating Leukocytes. Pharmacological Reports, 63, 1009-1018. http://dx.doi.org/10.1016/S1734-1140(11)70617-X

[37] Ishizawa, K., Yoshizumi, M., Kawai, Y., Terao, J., Kihira, Y., Ikeda, Y. and Tamaki, T. (2011) Pharmacology in Health Food: Metabolism of Quercetin in Vivo and Its Protective Effect against Arteriosclerosis. Journal of Pharmacological Science, 115, 466-470. http://dx.doi.org/10.1254/jphs.10R38FM

[38] Perez-Vizcaino, F., Bishop-Bailley, D., Lodi, F., Duarte, J., Cogolludo, A., Moreno, L. and Warner, T.D. (2006) The Flavonoid Quercetin Induces Apoptosis and Inhibits JNK Activation in Intimal Vascular Smooth Muscle Cells. Biochemical and Biophysical Research Communications, 346, 919-925. http://dx.doi.org/10.1016/j.bbrc.2006.05.198

[39] Larson, A.J., Symons, J.D. and Jalili, T. (2012) Therapeutic Potential of Quercetin to Decrease Blood Pressure: Review of Efficacy and Mechanisms. Advanced Nutrition, 3, 39-46. http://dx.doi.org/10.3945/an.111.001271

[40] Yoon, J.S., Chae, M.K., Lee, S.Y. and Lee, E.J. (2012) Anti-Inflammatory Effect of Quercetin in a Whole Orbital Tissue Culture of Graves’ Orbitopathy. British Journal of Ophthalmology, 96, 1117-1121. http://dx.doi.org/10.1136/bjophthalmol-2012-301537

[41] Granado-Serrano, A.B., Martín, M.Á., Bravo, L., Goya, L. and Ramos, S. (2012) Quercetin Attenuates TNF-Induced Inflammation in Hepatic Cells by Inhibiting the NF- $\kappa$ B Pathway. Nutrition \& Cancer, 64, 588-598. http://dx.doi.org/10.1080/01635581.2012.661513

[42] Chan, S.T., Chuang, C.H., Yeh, C.L., Liao, J.W., Liu, K.L., Tseng, M.J. and Yeh, S.L. (2012) Quercetin Supplementation Suppresses the Secretion of Pro-Inflammatory Cytokines in the Lungs of Mongolian Gerbils and in A549 Cells Exposed to Benzo[ $\alpha]$ Pyrene Alone or in Combination with $\beta$-Carotene: In Vivo and ex Vivo Studies. Journal of Nutrition Biochemistry, 23, 179-185. http://dx.doi.org/10.1016/j.jnutbio.2010.11.014

[43] Bhaskar, S., Kumar, K.S., Krishnan, K. and Antony, H. (2013) Quercetin Alleviates Hypercholesterolemic Diet Induced Inflammation during Progression and Regression of Atherosclerosis in Rabbits. Nutrition, 29, 219-229. http://dx.doi.org/10.1016/j.nut.2012.01.019

[44] Boots, A.W., Kubben, N., Haenen, G.R. and Bast, A. (2003) Oxidized Quercetin Reacts with Thiols Rather than with Ascorbate: Implication for Quercetin Supplementation. Biochemical and Biophysical Research Communication, 308, 560-565. http://dx.doi.org/10.1016/S0006-291X(03)01438-4

[45] Schimmer, O., Hafele, F. and Kruger, A. (1988) The Mutagenic Potencies of Plant Extract Containing Quercetin in Salmonella typhimurium TA98 and TA100. Mutation Research/Genetic Toxicology, 206, 201-208. http://dx.doi.org/10.1016/0165-1218(88)90161-9

[46] Cross, H.J., Tilby, M., Chipman, K., Ferry, D.R. and Gescher, A. (1996) Effect of Quercetin on the Genotoxic Potential of Cisplatin. International Journal of Cancer, 66, 404-408. http://dx.doi.org/10.1002/(SICI)1097-0215(19960503)66:3<404::AID-IJC23>3.0.CO;2-9

[47] Brown, J.P. and Dietrich, P.S. (1979) Mutagenicity of Plant Flavonols in the Salmonella/Mammalian Microsome Test: Activation of Flavonol Glycosides by Mixed Glycosidases from Rat Cecal Bacteria and Other Sources. Mutation Research/Genetic Toxicology, 66, 223-240. http://dx.doi.org/10.1016/0165-1218(79)90083-1

[48] Stoewsand, G.S., Anderson, J.L., Boyd, J.N., Hrazdina, J., Babish, J.G., Walsh, K.M. and Losco, P. (1984) Quercetin: Amutagen, Not a Carcinogen, in Fischer Rats. Journal of Toxicology Environmental Health, 14, 105-114. http://dx.doi.org/10.1080/15287398409530565

[49] Czeczot, H. (1994) Mutagenic Activity of Quercetin in Derivatives of Escherichia coli WP2 uvrA with Increased Per- 
meability. Acta Biochimica Polonica, 41, 144-147.

[50] Hardigree, A.A. and Epler, J.L. (1978) Comparative Mutagenesis of Plant Flavonoids in Microbial Systems. Mutation Research/Genetic Toxicology, 58, 231-239. http://dx.doi.org/10.1016/0165-1218(78)90014-9

[51] Rueff, J., Laires, A., Borba, H., Chaveca, T., Gomes, M. and Halpern, M. (1986) Genetic Toxicology of Flavonoids: The Role of Metabolic Conditions in the Induction of Reverse Mutation, SOS Function and Sister-Chromatid Exchanges. Mutagenesis, 1, 179-183. http://dx.doi.org/10.1093/mutage/1.3.179

[52] NTP (1992) Toxicology and Carcinogenesis Studies of Quercetin (CAS No. 117-39-5) in F344/N Rats (Feed Study). NTP Technical Report Series, No. 409, National Toxicology Program (NTP), Research Triangle Park (NC). https://ntp.niehs.nih.gov/ntp/htdocs/lt_rpts/tr409.pdf

[53] Umezawa, K., Matsushim, T., Sugimura, T., Hirakawa, T., Tanaka, M., Katoh, Y. and Takayama, S. (1977) In Vitro Transformation of Hamster Embryo Cells by Quercetin. Toxicology Letters, 1, 175-178. http://dx.doi.org/10.1016/0378-4274(77)90009-1

[54] van der Hoeven, J.C., Bruggeman, I.M. and Debets, F.M. (1984) Genotoxicity of Quercetin in Cultured Mammalian Cells. Mutation Research/Genetic Toxicology, 136, 9-21. http://dx.doi.org/10.1016/0165-1218(84)90130-7

[55] Caria, H., Chaveca, T., Laires, A. and Rueff, J. (1995) Genotoxicity of Quercetin in the Micronucleus Assay in Mouse Bone Marrow Erythrocytes, Human Lymphocytes, V79 Cell Line and Identification of Kinetochore-Containing (Crest Staining) Micronuclei in Human Lymphocytes. Mutation Research/Genetic Toxicology, 343, 85-94. http://dx.doi.org/10.1016/0165-1218(95)90075-6

[56] Harwood, M., Danielewska-Nikiel, B., Borzelleca, J.F., Flamm, G.W., Williams, G.M. and Lines, T.C. (2007) A Critical Review of the Data Related to the Safety of Quercetin and Lack of Evidence of in Vivo Toxicity, Including Lack of Genotoxic/Carcinogenic Properties. Food and Chemical Toxicology, 45, 2179-2205. http://dx.doi.org/10.1016/j.fct.2007.05.015

[57] Hard, G.C., Seeley, J.C., Betz, L.J. and Hayashi, S.M. (2007) Re-Evaluation of the Kidney Tumors and Renal Histopathology in 2-Year Rat Carcinogenicity Bioassay of Quercetin. Food and Chemical Toxicology, 45, 600-608. http://dx.doi.org/10.1016/j.fct.2006.10.018

[58] Utesch, D., Feige, K., Dasenbrock, J., Broschard, T.H., Harwood, M., Danielewska-Nikiel, B. and Lines, T.C. (2008) Evaluation of the Potential in Vivo Genotoxicity of Quercetin. Mutation Research/Genetic Toxicology and Environmental Mutagenesis, 654, 38-44. http://dx.doi.org/10.1016/j.mrgentox.2008.04.008

[59] Torchilin, V.P. (2007) Micellar Nanocarriers: Pharmaceutical Perspectives. Pharmaceutical Research, 24, 1-16. http://dx.doi.org/10.1007/s11095-006-9132-0

[60] Liu, D.S., Wei, Y.N., Yao, P.J. and Jiang, L.B. (2006) Determination of the Degree of Acetylation of Chitosan by UV Spectrophotometry Using Dual Standards. Carbohydrate Research, 341, 782-785. http://dx.doi.org/10.1016/j.carres.2006.01.008

[61] Aljawish, A., Chevalot, I., Piffaut, B., Rondeau-Mouro, C., Girardin, M., Jasniewski, J., Scher, J. and Muniglia, L. (2012) Functionalization of Chitosan by Laccase-Catalyzed Oxidation of Ferulic Acid and Ethyl Ferulate under Heterogeneous Reaction Conditions. Carbohydrate Polymers, 87, 537-544. http://dx.doi.org/10.1016/j.carbpol.2011.08.016

[62] Nguyen, S., Hisiger, S., Jolicoeur, M., Winnik, F.M. and Buschmann, M.D. (2009) Fractionation and Characterization of Chitosan by Analytical SEC and 1H NMR after Semi-Preparative SEC. Carbohydrate Polymers, 75, 636-645. http://dx.doi.org/10.1016/j.carbpol.2008.09.002

[63] Tang, Z.X., Qian, J.Q. and Shi, L.E. (2007) Preparation of Chitosan Nanoparticles as Carrier for Immobilized Enzyme. Applied Biochemistry and Biotechnology, 136, 77-96. http://dx.doi.org/10.1007/BF02685940

[64] Lin, C.C., Hsu, Y.F., Lin, T.C., Hsu, F.L. and Hsu, H.Y. (1998) Antioxidant and Hepatoprotective Activity of Punicalagin and Punicalin on Carbon Tetrachloride-Induced Liver Damage in Rats. Journal of Pharmacy and Pharmacology, 50, 789-794. http://dx.doi.org/10.1111/j.2042-7158.1998.tb07141.x

[65] Drury, R.A., Wallington, E.A. and Cancerson, R. (1980) Carlton’s Histopathological Techniques. 4th Edition, Oxford University Press, Oxford, London, New York.

[66] SAS Institute Inc. (1982) SAS User’s Guide: Statistics. SAS Institute Inc., Cary.

[67] Waller, R.A. and Duncan, D.B. (1969) A Bayes Rule for the Symmetric Multiple Comparisons Problem. Journal of the American Statistical Association, 64, 1484-1503. http://dx.doi.org/10.2307/2286085

[68] Feng, Y., Siu, K.Y., Ye, X., Wang, N., Yuen, M.F., Leung, C. H. and Kobayashi, S. (2010) Hepatoprotective Effects of Berberine on Carbon Tetrachloride-Induced Acute Hepatotoxicity in Rats. Chinese Medicine, 5, 33. http://dx.doi.org/10.1186/1749-8546-5-33

[69] Abdel-Azeim, S.H., Hassan, A.M., Salman, A.S., Waly, A.I. and Abdel-Wahhab, M.A. (2011) Genetic Alterations and 
Gene Expression Profile in Male Balb/c Mice Treated with Carbon Tetrachloride with or without Carboxymethyl Chitosan. Journal of American Science, 7, 1065-1076.

[70] Shanmugarajan, T.S., Prithwish, N., Somasundaram, I., Arunsundar, M., Niladri, M., Lavande, J.P. and Ravichandiran, V. (2008) Mitigation of Azathioprine-Induced Oxidative Hepatic Injury by the Flavonoid Quercetin in Wistar Rats. Toxicology Mechanisms and Methods, 18, 653-660. http://dx.doi.org/10.1080/15376510802205791

[71] Herlong, H.F. and Mitchell, M.C. (2012) Laboratory Tests. In: Schiff, E.R., Maddrey, W.C. and Sorrell, M.F., Eds., Schiff's Diseases of the Liver, 11th Edition, Wiley-Blackwell, Oxford. http://dx.doi.org/10.1002/9781119950509

[72] Khan, R.A., Khan, M.R., Sahreen, S. and Shah, N.A. (2012) Hepatoprotective Activity of Sonchus asper against Carbon Tetrachloride-Induced Injuries in Male Rats: A Randomized Controlled Trial. BMC Complementary and Alternative Medicine, 12, 90. http://dx.doi.org/10.1186/1472-6882-12-90

[73] El Denshary, E.S., Al-Gahazali, M.A., Mannaa, F.A., Salem, H.A., Hassan, N.S. and Abdel-Wahhab, M.A. (2012) Dietary Honey and Ginseng Protect against Carbon Tetrachloride-Induced Hepatonephrotoxicity in Rats. Experimental and Toxicological Pathology, 64, 753-760. http://dx.doi.org/10.1016/j.etp.2011.01.012

[74] Singhal, K.G. and Gupta, G.D. (2012) Hepatoprotective and Antioxidant Activity of Methanolic Extract of Flowers of Nerium oleander against $\mathrm{CCl}_{4}$-Induced Liver Injury in Rats. Asian Pacific Journal of Tropical Medicine, 5, 677-685. http://dx.doi.org/10.1016/S1995-7645(12)60106-0

[75] Yu, H., Zheng, L., Yin, L., Xu, L., Qi, Y., Han, X. and Peng, J. (2014) Protective Effects of the Total Saponins from Dioscorea nipponica Makino against Carbon Tetrachloride-Induced Liver Injury in Mice through Suppression of Apoptosis and Inflammation. International Immunopharmacology, 19, 233-244. http://dx.doi.org/10.1016/j.intimp.2014.01.019

[76] Khan, M.R. and Siddique, F. (2012) Antioxidant Effects of Citharexylum spinosum in $\mathrm{CCl}_{4}$ Induced Nephrotoxicity in Rat. Experimental and Toxicological Pathology, 64, 349-355. http://dx.doi.org/10.1016/j.etp.2010.09.009

[77] Hsouna, A.B., Saoudi, M., Trigui, M., Jamoussi, K., Boudawara, T., Jaoua, S. and Feki, A.E. (2011) Characterization of Bioactive Compounds and Ameliorative Effects of Ceratonia siliqua Leaf Extract against $\mathrm{CCl}_{4}$-Induced Hepatic Oxidative Damage and Renal Failure in Rats. Food and Chemical Toxicology, 49, 3183-3191. http://dx.doi.org/10.1016/j.fct.2011.09.034

[78] Adetoro, K.O., Bolanle, J.D., Abdullahi, S.B. and Ahmed, O.A. (2013) In Vivo Antioxidant Effect of Aqueous Root Bark, Stem Bark and Leaves Extracts of Vitex doniana in $\mathrm{CCl}_{4}$ Induced Liver Damage Rats. Asian Pacific Journal of Tropical Biomedicine, 3, 395-400. http://dx.doi.org/10.1016/S2221-1691(13)60083-0

[79] Jessup, J.M. and Thomas, P. (1998) CEA and Metastasis: A Facilitator of Site-Specific Metastasis. In: Stanners, C.P., Ed., Cell Adhesion and Communication Mediated by the CEA Family: Basic and Clinical Perspectives, Harwood Academic Publishers, Amsterdam, 195-222.

[80] Thomas, P., Toth, C.A., Saini, K.S., Jessup, J.M. and Steele Jr., G. (1990) The Structure, Metabolism and Function of the Carcinoembryonic Antigen Gene Family. Biochimica et Biophysica Acta (BBA)-Reviews on Cancer, 1032, 177-189. http://dx.doi.org/10.1016/0304-419X(90)90003-J

[81] Thomas, P. and Zamcheck, N. (1983) Role of the Liver in Clearance and Excretion of Circulating Carcinoembryonic Antigen (CEA). Digestive Disease and Science, 28, 216-224. http://dx.doi.org/10.1007/BF01295116

[82] Rosalki, S.B. and Mcintyre, N. (1999) Biochemical Investigations in the Management of Liver Disease. Oxford Textbook of Clinical Hepatology, 2nd Edition, Oxford University Press, New York, 503-521.

[83] Iwai, M., Morikawa, T., Muramatsu, A., Tanaka, S., Mori, T., Harada, Y. and Ishii, M. (2000) Biological Significance of AFP Expression in Liver Injury Induced by $\mathrm{CCL}_{4}$. Acta Histochemica et Cytochemica, 33, 17-22. http://dx.doi.org/10.1267/ahc.33.17

[84] Ragab, G.M., El-Denshary, E.S., Hassan, A.M., Abdel-Azeim, S.H., Hassan, N.S., Mannaa, F.A. and Abdel-Wahhab M.A. (2013) Grape (Vitis vinifera) Seed Extract Inhibits the Cytotoxicity and Oxidative Stress in Liver of Rats Treated with Carbon Tetrachloride. Global Journal of Pharmacology, 7, 258-269.

[85] Sun, T., Zhu, Y., Xie, J. and Yin, X.H. (2011) Antioxidant Activity of N-Acyl Chitosan Oligosaccharide with Same Substituting Degree. Bioorganic and Medicinal Chemistry Letters, 21, 798-800. http://dx.doi.org/10.1016/j.bmcl.2010.11.097

[86] Sarhan, N.A.Z., El-Denshary, E.S., Hassan, N.S., Abu-Salem, F.M. and Abdel-Wahhab, M.A. (2012) IsoflavonesEnriched Soy Protein Prevents $\mathrm{CCl}_{4}$-Induced Hepatotoxicity in Rats. ISRN Pharmacology, 2012, Article ID: 347930. http://dx.doi.org/10.5402/2011/949686

[87] Hou, F.L., Zhang, R.F., Zhang, M.W., Su, D.X., Wei, Z.C., Deng Y.Y., Zhang, Y., Chi, J.W. and Tang, X. (2013) Hepatoprotective and Antioxidant Activity of Anthocyanins in Black Rice Bran on Carbon Tetrachloride-Induced Liver Injury in Mice. Journal of Functional Foods, 5, 1705-1713. http://dx.doi.org/10.1016/j.jff.2013.07.015

[88] Wen, Z.S., Xu, Y.L., Zou, X.T. and Xu, Z.R. (2011) Chitosan Nanoparticles Act as an Adjuvant to Promote Both Th1 
and Th2 Immune Responses Induced by Ovalbumin in Mice. Marine Drugs, 9, 1038-1055. http://dx.doi.org/10.3390/md9061038

[89] Qi, L., Xu, Z. and Chen, M. (2007) In Vitro and in Vivo Suppression of Hepatocellular Carcinoma Growth by Chitosan Nanoparticles. European Journal of Cancer, 43, 184-193. http://dx.doi.org/10.1016/j.ejca.2006.08.029

[90] Yu, Z.B., Chai, D.R. and Tao, H. (2007) Antagonism of Nano-Chitosan against Mutagenic Effect of Different Mutagens to Salmonella typhinurium. Occupational Health, 19, 4-9.

[91] Qi, L.F., Xu, Z.R., Jiang, X., Hu, C.H. and Zou, X.F. (2004) Preparation and Antibacterial Activity of Chitosan Nanoparticles. Carbohydrate Research, 339, 2693-2700. http://dx.doi.org/10.1016/j.carres.2004.09.007

[92] Wen, Z.S., Liu, L.J., Qu, Y.L., OuYang, X.K., Yang, L.Y. and Xu, Z.R. (2013) Chitosan Nanoparticles Attenuate Hydrogen Peroxide-Induced Stress Injury in Mouse Macrophage RAW264.7 Cells. Marine Drugs, 11, 3582-3600. http://dx.doi.org/10.3390/md11103582

[93] Jeon, T.I., Hwang, S.G., Park, N.G., Jung, Y.R., Shin, S.I., Choi, S.D. and Park, D.K. (2003) Antioxidative Effect of Chitosan on Chronic Carbon Tetrachloride Induced Hepatic Injury in Rats. Toxicology, 187, 67-73. http://dx.doi.org/10.1016/S0300-483X(03)00003-9

[94] Subhapradha, N., Saravanan, R., Ramasamy, P., Srinivasan, A., Shanmugam, V. and Shanmugam, A. (2013) Hepatoprotective Effect of $\beta$-Chitosan from Gladius of Sepioteuthis lessoniana against Carbon Tetrachloride-Induced Oxidative Stress in Wistar Rats. Applied Biochemistry and Biotechnology, 172, 9-20. http://dx.doi.org/10.1007/s12010-013-0499-1

[95] Sivakumar, R., Rajesh, R., Buddhan, S., Jeyakum, R., Rajaprabhu, D., Ganesan, B. and Anandan, R. (2007) Antilipidemic Effect of Chitosan against Experimentally Induced Myocardial Infarction in Rats. Journal of Cell and Animal Biology, 1, 71-77.

[96] Anraku, M., Michihara, A., Yasufuku, T., Akasaki, K., Tsuchiya, D., Nishio, H., Maruyama, T., Otagiri, M., Maezaki, Y., Kondo, Y. and Tomida, H. (2010) The Antioxidative and Antilipidemic Effects of Different Molecular Weight chitosans in Metabolic Syndrome Model Rats. Biological and Pharmaceutical Bulletin, 33, 1994-1998. http://dx.doi.org/10.1248/bpb.33.1994

[97] Santhosh, S., Sini, T.K., Anandanand, R. and Mathew, P.T. (2006) Effect of Chitosan Supplementation on Anti-Tubercular Drugs-Induced Hepatotoxicity in Rats. Toxicology, 219, 53-59. http://dx.doi.org/10.1016/j.tox.2005.11.001

[98] El-Fattah, H.M.A., Abdel-Kader, Z.M., Hassnin, E.A., El-Rahman, M.K.A. and Hassan, L.E. (2013) Chitosan as a Hepatoprotective Agent against Single Oral Dose of Dioxin. IOSR Journal of Environmental Science, Toxicology and Food Technology (IOSR-JESTFT), 7, 11-17. http://dx.doi.org/10.9790/2402-0731117

[99] Mohamed, N.E. (2011) Effect of Chitosan on Oxidative Stress and Metabolic Disorders Induced in Rats Exposed to Radiation. Journal of American Science, 7, 406-417.

[100] Pavanato, A., Tuñón, M.J., Sánchez-Campos, S., Marroni, C.A., Llesuy, S., González-Gallego, J. and Marroni, N. (2003) Effects of Quercetin on Liver Damage in Rats with Carbon Tetrachloride-Induced Cirrhosis. Digestive Diseases and Sciences, 48, 824-829. http://dx.doi.org/10.1023/A:1022869716643

[101] Pilkhwal, S., Tirkey, N., Kuhad, A. and Chopra, K. (2010) Effect of Bioflavonoid Quercetin on Endotoxin Induced Hepatotoxicity and Oxidative Stress in Rat Liver. Iranian Journal of Pharmacology and Therapeutics, 9, 47-53.

[102] Kebieche, M., Lakroun, Z., Lahouel, M., Bouayed, J. and Meraihi, Z. (2009) Evaluation of Epirubicin-Induced Acute Oxidative Stress Toxicity in Rat Liver Cells and Mitochondria, and the Prevention of Toxicity through Quercetin Administration. Experimental and Toxicological Pathology, 61, 161-167. http://dx.doi.org/10.1016/j.etp.2008.06.002

[103] Padma, V.V., Baskaran, R., Roopesh, R.S. and Poornima, P. (2012) Quercetin Attenuates Lindane Induced Oxidative Stress in Wistar Rats. Molecular Biology Reports, 39, 6895-6905. http://dx.doi.org/10.1007/s11033-012-1516-0

[104] Abo-Salem, O.M., Abd-Ellah, M.F. and Ghonaim, M.M. (2011) Hepatoprotective Activity of Quercetin against Acrylonitrile-Induced Hepatotoxicity in Rats. Journal of Biochemical and Molecular Toxicology, 25, 386-392. http://dx.doi.org/10.1002/jbt.20406

[105] Nabavi, S.M., Nabavi, S.F., Eslami, S. and Moghaddam, A.H. (2012) In Vivo Protective Effects of Quercetin against Sodium Fluoride-Induced Oxidative Stress in the Hepatic Tissue. Food Chemistry, 132, 931-935. http://dx.doi.org/10.1016/j.foodchem.2011.11.070

[106] Tang, Y.H., Tian, H.T., Shi, Y.R., Gao, C., Xing, M.Y., Yang, W., Bao, W., Wang, D., Liu, L.G. and Yao, P. (2013) Quercetin Suppressed CYP2E1-Dependent Ethanol Hepatotoxicity via Depleting Heme Pool and Releasing CO. Phytomedicine, 20, 699-704. http://dx.doi.org/10.1016/j.phymed.2013.03.010

[107] Torres, E., Marrin, V., Aburto, J., Beltrán, H.I., Shirai, K., Villanueva, S. and Sandoval, G. (2012) Enzymatic Modification of Chitosan with Quercetin and Its Application as Antioxidant Edible Films. Applied Biochemistry and Microbiology, 48, 151-158. http://dx.doi.org/10.1134/S0003683812020123 